\title{
Pengaruh Model RME Berbasis Etnomatematika Terhadap Kemampuan Literasi Matematika Siswa Kelas IV SD Gugus 17 Kota Bengkulu.
}

\author{
Tivani Sandra Witha \\ Universitas Bengkulu \\ tivanithamrin@gmail.com \\ V.Karjiyati \\ Universitas Bengkulu \\ Vkarjiyati@gamil.com \\ Pebrian Tarmizi \\ Universitas Bengkulu \\ Tarmizifebrian28@gamil.com
}

\begin{abstract}
This study aims to determine the effect of ethnomatemics based Realistic Mathematics Education models on the mathematical literacy ability of grade IV elementary school students in the 17th city of Bengkulu on flat construction material. This research is a quantitative research. The research method used was quasi-experimental research using the matching only pretest-posttest control group design. The population in this study was the Elementary School Cluster 17 Bengkulu City. The sampling technique uses cluster random sampling. The sample in this study were students of class IV B Elementary School 04 Bengkulu City as an experimental class and students of class IV C Elementary School 11 Bengkulu as a control class. The research instrument used in the form of tests in the form of essay questions provided through pretest and posttest. The instrument used in the study was a test sheet in the form of a breakdown problem for the context of mathematical literacy. Based on the t-test calculation of students' posttest results, there is a tcount of $4.24>$ ttable of 2.01 , so it can be concluded that there is an influence of using ethnomatemics-based Realistic Mathematic Education models on the ability of mathematical literacy in the context components of class IV students in Cluster 17 Bengkulu City.
\end{abstract}

Keywords: realistic mathematics education model, ethnomatematics, mathematical literacy ability, flat build material.

\section{Pendahuluan}

Matematika merupakan salah satu kompenen dari serangkaian mata pelajaran yang mempunyai peranan penting dalam pendidikan. Berdasar pada pentingnya pembelajaran matematika maka mata pelajaran matematika diberikan mulai dari jenjang sekolah dasar hingga sekolah menengah. Matematika merupakan 
ilmu yang dapat memberikan kontribusi dalam penyelesaian masalah sehari-hari, serta dapat melatih berfikir logis, kritis dan kreatif.

Matematika memiliki objek kajian yang bersifat abstrak yaitu tidak berwujud dalam bentuk konkret atau nyata. Sejalan dengan pendapat Hadi (2017: 194) matematika merupakan ilmu yang abstrak dan bersifat formal, serta menggunakan simbol-simbol. Menurut Marti dalam Sundayana (2015: 3) Objek matematika yang abstrak tersebut merupakan kesulitan tersendiri yang harus dihadapi peserta didik dalam mempelajari matematika. Kesulitan dalam mempelajari matematika tersebut mengakibatkan kemampuan literasi matematika menjadi rendah.

Dalam Programme Internationale for Student Assesment (PISA) pada tahun 2018, kemampuan literasi matematika Indonesia dinyatakan rendah. Hal ini terbukti dengan skor yang masih di bawah rata-rata internasional. Skor rata-rata internasional menurut PISA untuk matematika adalah 494. Hasil penilaian PISA pada tahun 2018 menyatakan bahwa posisi kemampuan literasi matematika siswa Indonesia berada pada urutan ke 72 dari 78 Negara dengan skor 379. Data tersebut menunjukkan kemampuan literasi matematika siswa Indonesia masih di bawah rata-rata dan jauh tertinggal dari Negara lain.

Kemampuan literasi matematika merupakan cara siswa menerapkan pengetahuan dan keterampilannya untuk memecahkan masalah-masalah dalam kehidupan sehari-hari. Literasi erat kaitannya dengan kemampuan memecahkan masalah yang berkaitan dengan menulis, membaca, sains dan matematis. Menurut Abidin, dkk (2017: 237) Literasi matematika terdiri dari tiga komponen yaitu komponen proses yang berkaitan dengan upaya memecahkan masalah, komponen konten yang berkitan dengan materi-materi matematika yang dipelajari, dan komponen konteks yang berkitan dengan menggambarkan situasi permasalahan dalam kehidupan sehari-hari.

Dalam penelitian yang dilakukan oleh Fathani (2016) dalam jurnal "Pengembangan Literasi Matematika Sekolah dalam Perspektif Multiple Intelligences" Literasi matematika merupakan kemampuan seseorang untuk merumuskan, mengunakan dan menafsirkan matematika dalam berbagai konteks masalah kehidupan sehari-hari secara efisien. Dari segi proses, kemampuan ini tidak hanya terbatas pada kemampuan menghitung saja akan tetapi juga bagaimana mengkomunikasikan, menalar dan proses berfikir matematis lainnya.

Agar kemampuan literasi matematika siswa berkembang dibutuhkan objek konkret yang dapat ditangkap oleh panca indra pada roses pembelajaran. Hal ini dikarenakan siswa SD masih berada pada fase operasional konkret. Menurut Piaget dalam Umbara (2017: 37) pada usia 7-11 tahun siswa berada pada tahapan operasional-konkret. Pada usia ini siswa mulai memandang dunia secara objektif, bergeser dari satu aspek ke aspek lain secara reflektif dan memandang unsur-unsur serentak, mulai berpikir secara operasional serta mampu menggunakan cara berpikir operasional untuk mengklasifikasi benda-benda.

Tujuan pembelajaran matematika di sekolah dasar adalah agar siswa mampu dan terampil menggunakan matematika dalam kehidupan sehari-hari. Untuk mencapai tujuan tersebut, maka pembelajaran diarahkan kepada konsepkonsep. Konsep-konsep matematika akan mudah dipahami bila disajikan dalam bentuk kongkret, lalu diarahkan pada tahapan semi kongkret, dan pada akhirnya siswa dapat berfikir dan memahami matematika secara abstrak.

Agar siswa SD dapat memahami konsep-konsep matematika, maka pada proses pembelajaran dibutuhkan pembelajaran yang konkret dan kontekstual dengan menggunakan lingkungan sekitar. Model Realistic Mathematics Education (RME) merupakan model yang tepat untuk menanamkan konsep matematika di SD karena RME merupakan model pembelajaran yang menggunakan lingkungan sekitar/lingkungan sehari-hari. Sejalan dengan pendapat Wijaya (2012: 20) Realistic Mathematics Education merupakan pendekatan yang menekankan pembelajaran 
dengan situasi dunia nyata yang dapat dibayangkan oleh siswa. RME memberikan pengertian yang jelas kepada siswa tentang keterkaitan matematika dengan kehidupan sehari-hari dan kegunaan matematika. Hal ini sejalan dengan pendapat Karjiyati, dkk (2014: 231) bahwa dalam pelaksanaannya menempatkan realita dan pengalaman siswa sebagai titik awal pembelajaran.

Dalam penelitian yang dilakukan Fauzan (2013) dalam jurnal "Pengaruh Pendekatan RME dan Kemandirian Belajar Terhadap Kemampuan Matematis Siswa" bahwa RME dapat mengembangkan kemampuan mereka dalam memahami masalah, menemukan strategi-strategi yang bervariasi dalam memecahkan masalah, dan memberikan penafsiran yang tepat terhadap solusi yang diperoleh. Sejalan dengan pendapat Wibowo (2017) dalam jurnal "Pengaruh Pendekatan Pembelajaran Matematika Realistik dan Saintifik terhadap Prestasi Belajar, Kemampuan Penalaran Matematis dan Minat Belajar" bahwa pendekatan pembelajaran realistik efektif terhadap prestasi belajar, kemampuan penalaran matematis, dan minat belajar siswa.

Pada proses pembelajaran menggunakan model RME bisa menggunakan sumber belajar berbasis budaya. Pembelajaran yang menghubungkan antara matematika dan budaya disebut etnomatematika. Menurut Supriadi (2017: 22) etnomatematika merupakan disiplin ilmu yang mengaitkan matematika dengan budaya dan nilai-nilai sosial dalam kehidupan. Dengan menerapakan etnomatematika sebagai suatu pendekatan pembelajaran akan sangat memungkinkan suatu materi yang dipelajari dapat dipahami dengan mudah oleh siswa karena materi tersebut terkait langsung dengan budaya mereka yang merupakan aktivitas mereka sehari-hari dalam bermasyarakat.

Bengkulu memiliki banyak budaya yang dapat digunakan sebagai sumber belajar matematika, diantaranya adalah Rumah Adat Bubungan Limo. Pada Rumah Adat Bubungan Limo terdapat banyak model bangun datar, diantaranya ada segibanyak beraturan dan segibanyak tidak beraturan. Dalam kurikulum 2013 pada kelas IV, terdapat Kompetensi Dasar (KD) 3.8 Menganalisis sifat-sifat segibanyak beraturan dan segibanyak tidak beraturan. Kompetensi Dasar (KD) 4.8 Mengidentifikasi segibanyak beraturan dan segibanyak tidak beraturan.

Dalam penelitian yang dilakukan oleh Marsigit, dkk (2017) dalam jurnal "Pengembangan Pembelajaran Matematika Berbasi Etnomatematika" bahwa pembelajaran matematika berbasis etnomatematika di SD mampu meningkatkan siswa berpikir kritis, meningkatkan pemahaman matematika siswa dan meningkatkan upaya siswa mengkonstruksi konsep dan struktur matematika. Sejalan dengan pendapat Richardo (2016) dalam jurnal "Peran Etnomatematika dalam Penerapan Pembelajaran Matematika pada Kurikulum 2013" bahwa etnomatematika memfasilitasi siswa untuk mengkonstruksi konsep matematika dengan pengetahuan awal yang sudah mereka ketahui karena melalui lingkungan sekitar.

Dari uraian di atas, maka peneliti ingin melakukan penelitian untuk melihat pengaruh model Realistic Mathematics Education berbasis etnomatematika terhadap kemampuan literasi matematika siswa kelas IV gugus 17 Kota Bengkulu pada materi bangun datar.

\section{Metode}

Populasi dalam penelitian ini adalah siswa kelas IV SD Gugus 17 Kota Bengkulu. Untuk menentukan sampel dalam penelitian ini dengan teknik cluster random sampling. Sampel pada penelitian kelas IVC SDN 11 Kota Bengkulu sebagai kelas eksperimen dan IVB SDN 04 Kota Bengkulu sebagai kelas kontrol.

Instrumen penelitian ini diawali dengan menyusun kisi-kisi instrument dan kisi-kisi soal. Bentuk soal yang dibuat berupa soal essai untuk komponen konteks. Soal dibuat berdasarkan indikator-indikator yang telah disesuaikan dengan kompetensi dasar dan materi pelajaran yang digunakan dalam penelitian ini. 
Seluruh soal yang telah dibuat kemudian dikonsultasikan dengan ahli dalam bidangnya sebagai validasi isi. Setelah divalidasikan soal diuji cobakan. Setelah soal diuji cobakan dilakukan uji validitas, reliabilitas, taraf kesukaran dan daya beda. Sehingga didapatkan instrument penelitian berjumlah 4 soal dari 6 soal yang di validasikan.

Teknik pengumpulan data yang menggunakan pretest dan posttest. Pretest dilakukan sebelum dilaksanakan pembelajaran untuk mengetahui kemampuan awal siswa. Setelah dilakukan pretest dilakukan pembelajaran dan diberikan perlakuan. Setelah dilakukan proses pembelajaran siswa di berikan posttest untuk megetahui sejauh mana pengaruh dari model RME berbasis etnomatematika terhadap kemampuan literasi matematika.

Teknik analisis data menggunakan analisis deskriptif (menghitung rata-rata, dan varian), analisis uji prasyarat ( menghitung uji normalitas dan uji homogenitas), analisis inferensial (uji-T).

\section{Hasil}

Kemampuan siswa yang dianalisis dalam penelitian ini adalah kemampuan literasi matematika siswa pada aspek kongntif mata pelajaran matematika. Adapun hasil pretest dan posttest, disajikan pada tabel 4.1

Tabel 4.1 Hasil Pretest dan Posttest Kelas Eksperimen dan Kelas Kontrol

\begin{tabular}{|ccccc|}
\hline \multirow{2}{*}{ Deskripsi } & \multicolumn{2}{c}{ Pretest } & \multicolumn{2}{c|}{ Posttest } \\
& Eksperimen & Kontrol & Eksperimen & Kontrol \\
\hline Nilai Tertinggi & 95 & 90 & 100 & 90 \\
\hline Nilai Terendah & 5 & 0 & 35 & 25 \\
\hline Rata-rata & 54.500 & 47.773 & 79.417 & 61.136 \\
\hline Standar Deviasi & 30.86 & 23.980 & 17.14 & 20.608 \\
\hline Varian & 952.170 & 575.064 & 294.00 & 424.69 \\
\hline Normalitas & 9.83 & -51.73 & 6.2 & -6.56 \\
\hline Homogenitas & 1.656 & \multicolumn{3}{c|}{0.69} \\
\hline Uji-t & 1.27 & \multicolumn{3}{c}{4.24} \\
\hline
\end{tabular}

Berdasarkan data pada tabel 4.1, kemampuan awal literasi matematika siswa antara kelas eksperimen dan kelas kontrol memiliki rata-rata yang tidak terlalu berbeda yaitu 54,50 untuk kelas eksperimen dan 47,77 pada kelas kontrol. Uji normalitas menunjukkan bahwa nilai $9,83<11,07$ pada kelas eksperimen dan -51,73 $<11,07$ pada kelas kontrol, yang artinya kedua sampel penelitian ini berdistribusi normal. Nilai uji homogenitas adalah $1,66<2,06$ dan kedua sampel dinyatakan homogen. Nilai uji $t$ 1,27 $<2,01$ maka Ho diterima. Artinya, tidak terdapat perbedaan kemampuan awal literasi matematika antara kelas kontrol dan kelas eksperimen.

Setelah dilakukan pembelajaran maka dilaksanakan postest. Berdasarkan data pada tabel 4.1, kemampuan akhir literasi matematika antara kelas eksperimen dan kelas kontrol memiliki rata-rata yang jauh berbeda yaitu kelas kontrol memiliki rata-rata 61,14 sedangkan kelas eksperimen memiliki nilai rata-rata sebesar 79,41. Uji normalitas menunjukkan bahwa nilai $6,2<11,07$ pada kelas eksperimen dan $-61,13<$ 11,07 pada kelas kontrol, yang artinya kedua sampel penelitian ini berdistribusi normal. Hasil uji homogenitas antara kelas kontrol dan kelas eksperimen diperoleh nilai sebesar 0,69<2,06 dan kedua sampel dinyatakan homogen. Nilai uji t 4,24> 2,01 maka Ho ditolak. Artinya, terdapat perbedaan yang signifikan antara kemampuan literasi matematika kelas kontrol dan kelas eksperimen.

Adapun nilai rata-rata kemampuan literasi matematika Pretest dan Posttest Kelas Eksperimen dan Kelas Kontrol disajikan pada diagram di bawah ini. 


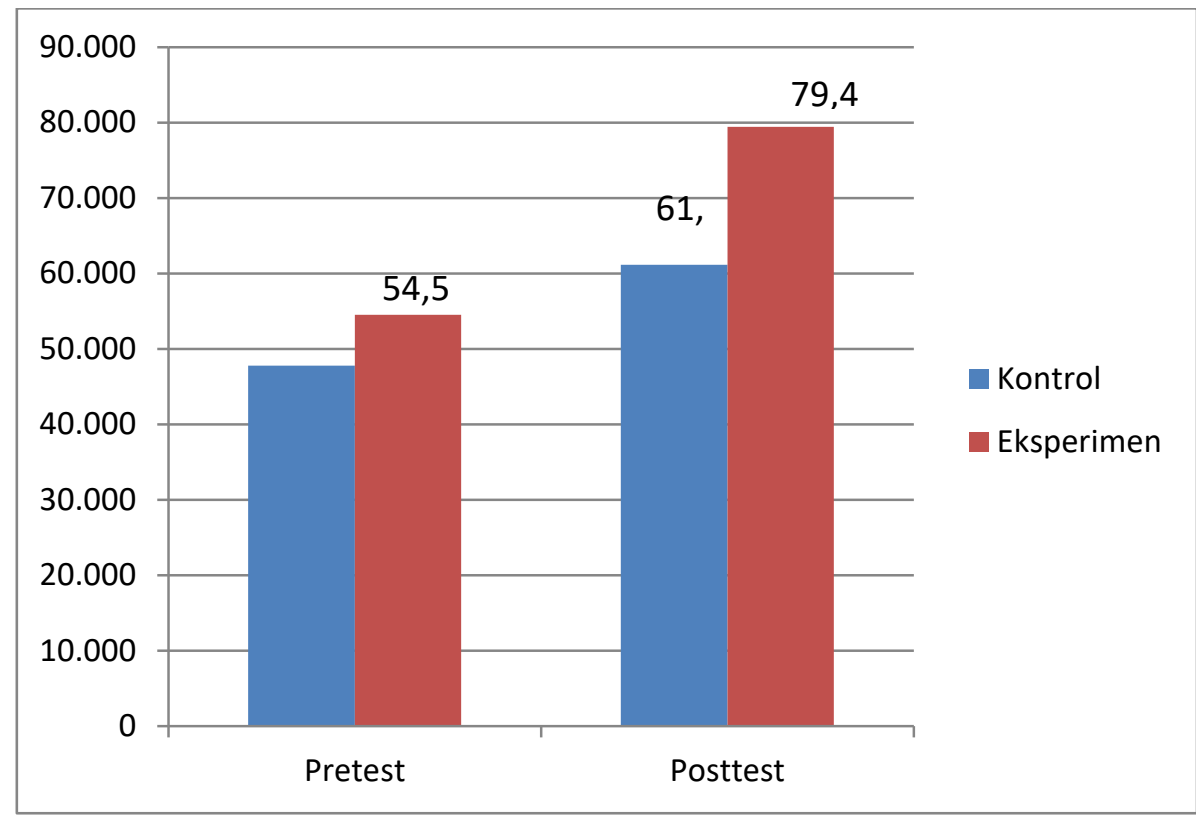

Diagram 4.1 Nilai rata-rata Kemampuan Literasi matematika Pretest dan Posttest Kelas Eksperimen dan Kelas Kontrol

\section{Pembahasan}

Pada penelitian ini, sebelum melaksanakan pembelajaran pada kelas eksperimen dan kelas kontrol, terlebih dahulu kedua kelas sampel tersebut diberikan lembar pretest. Dari hasil pretest kelas eksperimen dan kontrol diperoleh nilai rata-rata kedua kelas yaitu kelas kelas kontrol sebesar 47,773 dan kelas eksperimen sebesar 54,500. Berdasarkan uji statistik tidak terdapat perbedaan hasil pretest antara kelas eksperimen dan kelas kontrol, maka dapat disimpulkan bahwa kemampuan awal siswa pada kelas eksperimen dan kontrol sama.

Setelah diberikan pretest, selanjutnya kelas diberikan perlakuan. Pada kelas eksperimen dan kontrol dilaksanakan pembelajaran berdasarkan Rencana Pelaksanaan Pembelajaran (RPP) yang sudah dirancang sebelumnya. Pada saat proses pembelajaran dikelas kontrol diberikan perlakuan yaitu dengan menggunakan model realistic mathematics education berbasis etnomatematika Rumah Adat Bubungan Limo, sedangkan pada kelas kontrol pembelajaran dilaksanakan secara konvensional dengan model ekspositori.

Proses pembelajaran pada kelas eksperimen menggunakan model Realistic Mathematics Education dan miniatur Rumah Adat Bubungan Limo, adapun langkah-langkah pembelajaran yang dilakukan yaitu yang pertama memahami masalah kontekstual, pada langakah ini guru menunjukkan miniatur Rumah Adat Bubungan limo dan siswa diminta untuk menyebutkan macam-macam bangun datar yang terdapat pada minitur tersebut. Pemanfaatan Rumah Adat Bubungan Limo menumbuhkan memotivasi belajar, siswa sangat antusias dan bertanya mengenai materi pembelajaran sehingga minat belajarnya tinggi. Hal ini sejalan dengan pendapat Melisa, dkk (2019) menegaskan bahwa, pembelajaran bermuatan matematika realistic berbasis etnomatematika akan memberikan motivasi belajar serta pemahaman konsep suatu materi oleh siswa menjadi lebih mudah karena materi tersebut terkait langsung dengan budaya mereka, yang merupakan aktivitas mereka sehari-hari dalam masyarakat.

Langkah kedua yaitu memecahkan masalah kontekstual, pada langkah ini siswa Siswa dibentuk menjadi 4 kelompok yang heterogen untuk menyelesaikan LKPD. Pada langkah ini guru memberikan petunjuk penyelesaian LKPD untuk memudahkan siswa dalam menyelesaikan LKPD. Siswa diberikan miniatur Rumah 
Adat Bubungan Limo. Selanjutnya, siswa mengukur sisi bangun segibanyak pada miniatur Rumah Adat Bubungan Limo menggunakan peggaris untuk mencari sifatsifat segibanyak. Guru sambil berkeliling memberikan kesempatan kepada siswa bertanya jika ada yang belum dipahami. Hal ini sejalan dengan pendapat Shoimin (2014:148) menyebutkan salah satu prinsip realistic mathematics education yaitu bimbingan, ketika siswa menemukan sendiri prinsip, konsep atau rumus matematika dan siswa mengalami kesulitan maka guru akan membimbing.

Langkah ketiga yaitu membandingkan dan mendiskusikan jawaban, pada langkah ini siswa melakukan diskusi jawaban pada kelompok masing-masing lalu jawaban dipaparkan di depan kelas oleh setiap kelompok dan setiap kelompok membandingkan jawabannya. Hampir setiap siswa dalam kelompok terlibat aktif serta sungguh-sungguh bekerjasama. Pada tahap ini pengetahuan dan pemahaman siswa berkaitan materi yang dipelajari bertambah sehingga siswa dapat menyelesaikan masalah dengan baik dan kemampuan literasi matematika siswa berkembang. Hal ini sejalan dengan pendapat Johar dalam Nabilah Mansyur Penguasaan matematika yang baik dapat membantu siswa menyelesaikan masalah sehingga mengembangkan kemampuan literasi matematika.

Langkah terakhir yaitu menarik kesimpulan, pada langkah ini guru memberikan penguatan dan pemantapan materi dan melakukan tanya jawab mengenai pembelajaran yang telah dipelajari. Kemudian, siswa menyimpulkan hasil pembelajaran. Hal ini sesuai dengan pendapat Wahyuni (2013: 116) mengatakan bahwa dengan menggunakan etnomatematika dalam pembelajaran matematika membuat siswa mudah dalam memahami materi yang disampaikan guru, dan dapat meningkatkan hasil belajar siswa.

Dengan miniatur Rumah Adat Bubungan Limo siswa dapat menentukan bangun segibanyak dan menganalisis sifat-sifat bangun segibanyak yang terdapat pada miniatur tersebut. Setelah mereka mengetahui sifat-sifat bangun segibanyak, mereka dapat menentukan mana yang termasuk segibanyak beraturan dan segibanyak tidak beraturan. Model Realistic Mathematics Education berbasis etnomatematika dapat membantu siswa menemukan sifat-sifat bangun segibanyak dengan mudah dan menyenangkan, karena miniatur Rumah Adat Bubungan Limo merupakan sumber belajar yang konkret dan siswa telah mengenal Rumah Adat Bubungan Limo karena terkait langsung dengan budaya mereka.

Pada kelas kontrol dilakukan pembelajaran berdasarkan Rencana Pelaksanaan Pembelajaran (RPP) yang telah dirancang sebelumnya. Proses pembelajaran pada kelas kontrol menggunakan model ekspositori dan gambar Rumah Adat Bubungan Limo, adapun langkah-langkah pembelajaran yang dilakukan yaitu yang pertama penyajian, pada langkah ini guru memberikan penjelasan mengenai materi sifat-sifat segibanyak beraturan dan tidak beraturan. Langkah kedua yaitu korelasi, pada langkah ini siswa dibagi menjadi 4 kelompok dan diberikan gambar Rumah Adat Bubungan Limo. Guru memberikan contoh soal dan cara mengerjakannya, sedangkan siswa memperhatikan guru menjelaskan bagaimana mengerjakan contoh soal dengan mengamati gambar Rumah Adat Bubungan Limo. Langkah ketiga yaitu menyimpulkan, pada langkah ini guru dan siswa menyimpulkan pembelajaran yang telah dilakukan. Dan langkah terakhir yaitu mengaplikasikan, pada langkah ini siswa mengerjakan soal latihan.

Setelah diberikan perlakuan pada kelas kontrol dan kelas eksperimen, maka diberikan posttest. Dari hasil posttest kelas eksperimen dan kelas kontrol diperoleh nilai rata-rata kedua kelas yaitu kelas kontrol sebesar 61,14 dan kelas eksperimen sebesar 79,42. Berdasarkan uji statistik terdapat perbedaan hasil posttest antara kelas eksperimen dan kelas kontrol, sehingga dapat disimpulkan bahwa pembelajaran dengan menggunakan model realistic mathematic education berbasis etnomatematika Rumah Adat Bubungan Limo lebih unggul dibandingkan pembelajaran dengan model

ekspositori yang menggunakan media gambar. Hal ini dikarenakan kelas eksperimen menemukan sendiri konsep bangun segibanyak beraturan dan 
segibanyak tidak beraturan. Sedangkan pada kelas kontrol siswa hanya mengamati gambar dan mendengarkan penjelasan guru sehingga kemampuan siswa untuk mengingat konsep lebih rendah. Sejalan dengan pendapat Wahyu (2012: 7) $R M E$ memiliki keunggulan yaitu memberikan permasalahan kepada siswa yang erat kaitannya dengan lingkungan sehari-hari siswa.

\section{Simpulan}

Berdasarkan hasil penelitian dan pembahasan, maka dapat disimpulkan pada uji-t posttest komponen konteks literasi matematika, thitung lebih besar dari $t_{\text {tabel. }}$. Dengan nilai thitung $(4,24)>t_{\text {tabel }}(2,01)$, dapat disimpulkan bahwa thitung lebih besar dari tabel artinya Ha diterima dan terdapat pengaruh penggunaan model Realistic Mathematics Education berbasis etnomatematika terhadap kemampuan literasi pada komponen konteks siswa kelas IV Gugus 17 Kota Bengkulu.

\section{Saran}

Berdasarkan hasil penelitian yang dilakukan, maka peneliti mengemukakan beberapa saran. Bagi guru diharapkan menggunakan model Realistic Mathematics Education berbasis etnomatematika karena dalam proses pembelajaran anak menjadi lebih antusias dan semangat sehingga pembelajaran menjadi menarik dan bermakna. Guru disarankan menggunakan miniatur Rumah Adat Bubungan Limo yang ukurannya lebih besar agar setiap siswa dalam kelompok lebih mudah menganalisis sifat-sifat segibanyak beraturan dan tidak beraturan. Guru disarankan membagi siswa kedalam kelompok yang beranggotakan kurang dari 4 siswa agar siswa lebih kondusif saat bekerja di dalam kelompok.

Bagi peneliti lain (yang ingin menindaklanjuti penelitian ini) disarankan untuk meneliti kemampuan literasi pada materi yang berbeda selain sifat-sifat segibanyak beraturan dan tidak beraturan. Peneliti lain disarankan menggunakan etnomatematika yang berbeda dari Rumah Adat Bubungan Limo. Peneliti lain disarankan mengukur kemampuan literasi selain komponen konteks, misalnya pada komponen proses dan konten.

\section{Referensi}

Abidin, dkk., (2017), Pembelajaran Literasi, Strategi Meningkatkan Kemampuan Literasi Matematika, Sains, Membaca dan Menulis, Jakarta : Bumi Aksara.

Fathani, A. H., (2016), Pengembangan Literasi Matematika Sekolah dalam Perspektif Multiple Intelligences. ISSN: 2338-4387, Vol. 04, No. 02.

Fauzan, A. dkk. (2013), Pengaruh Pendekatan RME dan Kemandirian Belajar Terhadap Kemampuan Matematis Siswa.

Hadi, S., (2017), Pendidikan Matematika Realistik, Jakarta : PT Raja Grafindo Persada.

Karjiyati. V, dkk., (2014), Jurnal Pengembangan Model Quantum Teaching Dalam Pembelajaran Matematika Menggunakan Realistic Mathematics Education Untuk Meningkatkan Prestasi Belajar, Kreativitas Dan Karakter Siswa SD, ISSN: 16938577, Vol. 7, No. 02.

Khikmiyah, F, dkk., (2016), Pengembangan Buku Ajar Literasi Matematika, Jurnal Silogisme: Kajian Ilmu Matematika dan Pembelajarannya, Vol. 01, No. 02.

Marsigit, dkk., (2017), Jurnal Pengembangan Pembelajaran Matematika Berbasis Etnomatematika, ISBN: 978-602-6258-07-6.

Maulana., (2017), Membangun Generasi Emas 2045 yang Berkarakter dan Melek IT dan Pelatihan Berpikir Suprarasional, Prosiding Seminar Nasional, ISBN: 978-602-6238-10-2. 
Witha, T.S., Karjiyati, V., Tarmizi, P.

Melisa, dkk., (2019), Pembelajaran Matematika Realistik Berbasis Etnomatematika Bengkulu untuk Meningkatkan Kognisi Matematis, Jurnal Pendidikan Matematika Raflesia, Vol. 04, No. 02.

Ricardo, R., (2016), Peran Etnomatematika dalam Penerapan Pembelajaran Matematika pada Kurikulum 2013, Vol. 07, No.02.

Shoimin, A., (2014), 68 Model Pembelajaran Inovatif dalam Kurikulum 2013, Yogyakarta: Ar-ruzz Media.

Supriadi., (2017), Cara Mengajar Matematika untuk PGSD 1, Banten: PGSD UPI Kampus Serang.

Umbara, U., (2017), Psikologi Pembelajaran Matematika, Melaksanakan Pembelajaran Matematika Berdasarkan Tinjaun Psikologi, Yogyakarta: Deepublish.

Wahyuni, A., (2013), Peran Etnomatematika dalam Membangun Karakter Bangsa, Yogyakarta: UPI Press.

Wibowo, A., (2017), Pengaruh Pendekatan Pembelajaran Matematika Realistik dan Saintifik terhadap Prestasi Belajar, Kemampuan Penalaran Matematis dan Minat Belajar, Jurnal Riset Pendidikan Matematika, ISSN: 2356-2684.

Wijaya, A., (2012), Pendidikan Matematika Realistik, Suatu Alternatif Pendekatan Pembelajaran Matematika, Yogyakarta: Graha Ilmu

Zulkentati., (2018), Efektifitas Metode Eksperimen dalam Meningkatkan Hasil Belajar pada Pembelajaran Ilmu Pengetahuan Alam di Sekolah Dasar, Indargiri Journal, Vol 1, No. 4. 